\title{
Bacterial generation of liquid arsenic waste and the application of water-soluble polymers for arsenic ions separation
}

\author{
Bernabé L. Rivas $\cdot$ Zygmunt Sadowski
}

Published online: 27 May 2014

(C) The Author(s) 2014. This article is published with open access at Springerlink.com

\begin{abstract}
Two aspects of the bio-geo-chemical arsenic cycle in the environment are analysed. The bioleaching and chemical weathering of selected arsenic bearing minerals are presented. The natural bacteria adaption to the higher concentration of arsenic ions is described. The secondary precipitation of minerals containing arsenic was discussed regarding the immobilisation of arsenic ions in soil. Water-soluble polymers are combined with membranes to remove arsenic species under different experimental conditions.
\end{abstract}

Keywords Bioleaching $\cdot$ Weathering $\cdot$ Arsenic minerals - Arsenic tolerance $\cdot$ Precipitation ·

Water-soluble polymers $\cdot$ Membranes

\section{Introduction}

Arsenic is mobilised in the environment by processes such as weathering, biological activity, volcanic emissions, and anthropogenic mining activity. Acidic rock drainage (ARD) solutions are formed through the chemical and biological weathering of sulphide

B. L. Rivas

Faculty of Chemistry, University of Concepcion,

Concepción, Chile

\section{Z. Sadowski ( $\square)$}

Department of Chemical Engineering, Wroclaw

University of Technology, Wroclaw, Poland

e-mail: zygmunt.sadowski@pwr.wroc.pl minerals (Basu and Schreiber 2013). The predominant sulphide mineral subject to bacterial action is pyrite. However, pyrite-rich deposits often contain arsenicbearing minerals, such as arsenopyrite (FeAsS), orpiment $\left(\mathrm{As}_{2} \mathrm{~S}_{3}\right)$, realgar (AsS), and lulingite $\left(\mathrm{FeS}_{2}\right)$. Consequently, acidic rock drainage contains arsenic ions. Many bacteria contribute to the biological leaching of arsenic-bearing materials. Bioleaching processes have found various applications during the recovery of copper, zinc, cobalt, lead, uranium and gold (Bosecker 1997). However, these bioleaching processes can release arsenic ions.

Microbial-mineral interactions are important because acidic rock drainage is a widespread environmental problem. For arsenic pollution, the typical arsenic ions concentration in fresh water is $<10 \mu \mathrm{g} / \mathrm{l}$. A serious problem exists in Bangladesh and West Bengal, where the As concentration in the groundwater exceeds $50 \mu \mathrm{m} / \mathrm{l}$ (Jong and Parry 2005, Tareq et al. 2003). The maximum contaminant level for arsenic in drinking water, is $10 \mu \mathrm{g} / \mathrm{l}$. In drinking water, arsenic is primarily present as arsenite $\left(\mathrm{AsO}_{2}{ }^{-}\right)$and arsenate $\left(\mathrm{AsO}_{3}{ }^{-}\right)$ions. Removing of arsenic ions from groundwater is a global task. This paper presents the bioleaching processes with arsenic-bearing minerals and includes a selective method for removing the arsenic ions from water.

\subsection{Bioleaching of arsenic-bearing minerals}

Arsenopyrite (FeAsS) is the dominant naturally occurring arsenic-bearing mineral. Arsenopyrite weathering 
involves mineral oxidation and bioleaching (Igarashi et al. 2008). The physicochemical conditions of arsenopyrite bioleaching were studied by Cruz et al. (2005). The presence of bacteria, such as Acidothiobacillus ferrooxidans, in mining wastes containing arsenopyrite promotes the formation of acidic mine drainage that contains arsenic ions. The bio-oxidation processes that dissolve that arsenopyrite occur at the mineral surface and in bacteria cells. The cells adhere to the mineral surface depending on both hydrophobic and electrostatic interactions. Electrophoretic mobility measurements showed that arsenopyrite exhibits an isoelectric point at pH 3.5 in K2 media (Cruz et al. 2005). The bacteria cells provide a negative charge under these conditions. Therefore, the electrostatic attraction between the microbial cells and the mineral surface should occur. Arsenopyrite dissolves over a wide range of $\mathrm{pH}$ values (from 3 to 10). Arsenopyrite decomposes as follow:

$$
\begin{aligned}
& \mathrm{FeAsS}+7 \mathrm{H}_{2} \mathrm{O} \rightarrow \mathrm{Fe}^{2+}+\mathrm{H}_{3} \mathrm{AsO}_{3}+11 \mathrm{H}^{+} \\
& +\mathrm{SO}_{4}^{2-}+11 \mathrm{e}^{-}
\end{aligned}
$$

Orpiment $\left(\mathrm{As}_{2} \mathrm{~S}_{3}\right)$ involves a group of arsenic-bearing minerals associated with both pyrite and arsenopyrite. Orpiment dissolution increases linearly when moved from acidic to alkaline conditions (Suess and PlanerFriedrich 2012). Orpiment oxidation may be written as follows:

$$
\mathrm{As}_{2} \mathrm{~S}_{3}+6 \mathrm{O}_{2}+6 \mathrm{H}_{2} \mathrm{O} \rightarrow 2 \mathrm{H}_{3} \mathrm{AsO}_{3}+3 \mathrm{SO}_{4}^{2-}+6 \mathrm{H}^{+}
$$

Studying orpiment and arsenopyrite dissolution showed that thioarsenate can form as the dominant species at neutral and alkaline conditions. The formation of thioarsenate during the first step of dissolution increases the mineral dissolution (Suess and PlanerFriedrich 2012).

Realgar $\left(\mathrm{As}_{2} \mathrm{~S}_{2}\right)$ is also associated with goldbearing minerals (Lengker and Tempel 2003). Weathered or bioleached realgar releases arsenic into the environment. Metal ions, such as $\mathrm{Ag}^{+}$and $\mathrm{Cu}^{2+}$, can enhance the leaching rate by creating $\mathrm{AgS}_{2}$ and $\mathrm{CuS}$ species on the surface of the realgar (Guo et al. 2011).

Energite $\left(\mathrm{Cu}_{3} \mathrm{AsS}_{4}\right)$ is the primary arsenic-bearing component of copper ores. Energite is present in several Chilean copper deposits (Escobar et al. 2000). Bioleached energite initially produces $\mathrm{As}^{3+}$ ions that are later oxidised to $\mathrm{As}^{5+}$. The direct and indirect bioleaching processes of energite occur as follows (Song et al. 2008):

$$
\begin{gathered}
\mathrm{Cu}_{3} \mathrm{AsS}_{4}+2.5 \mathrm{O}_{2}+2 \mathrm{H}_{2} \mathrm{O}+\text { (bacteria) } \\
\rightarrow 3 \mathrm{Cu}^{2+}+\mathrm{AsO}_{2}^{-}+2.5 \mathrm{H}_{2} \mathrm{O} \\
+4 \mathrm{~S} \text { (direct bioleaching) } \\
\mathrm{Cu}_{3} \mathrm{AsS}_{4}+9 \mathrm{Fe}^{3+}+2 \mathrm{H}_{2} \mathrm{O} \\
\rightarrow 3 \mathrm{Cu}^{2+}+9 \mathrm{Fe}^{2+}+4 \mathrm{~S}^{0}+\mathrm{AsO}_{2}^{-} \\
+4 \mathrm{H}^{+} \text {(indirect bioleaching) }
\end{gathered}
$$

The second step (arsenic ions oxidation) occurs as follows:

$\mathrm{AsO}_{2}^{-}+2 \mathrm{Fe}^{3+} \rightarrow \mathrm{AsO}_{4}^{3-}+2 \mathrm{Fe}^{2+}+4 \mathrm{H}^{+}$

Energite bioleaching experiments using a thermophilic strain called Sulfolobus at $70{ }^{\circ} \mathrm{C}$ showed that the final concentration of arsenic in a leaching solution was only $3.9 \%$. The low arsenic concentration was due to ferric arsenate precipitation (Escobar et al. 2000).

The dissolution of arsenopyrite releases arsenic, sulphur, and iron, which haves additional influences on the arsenic oxidation. It was shown that the oxidation of $\mathrm{As}$ (III) by $\mathrm{Fe}$ (III) is catalysed by pyrite and chalcopyrite under acid bioleaching condition (Mandl et al. 1996).

Natural weathering and bioleaching of arsenicbearing minerals, particularly arsenic-sulphides, are sources for the arsenic released into the environment. Generally, the bioleaching of gold-bearing sulphides ores produces solutions containing several grams per litre of arsenic. The efficiency of bioleaching is strongly affected by the type of arsenic-bearing mineral. However, the rapid bio-oxidation of As(III) to $\mathrm{As}(\mathrm{V})$ can decrease arsenic migration to the soil. Several arsenicoxidising bacteria have been isolated (Battaglia-Brunet et al. 2011): Achromobacter, Pseudomonas, Alcaligenes, Rhizobium, Sinorhizobium, Bordetella, Agrobacterium, Thermus, Herminiomonas, Variovarax, and Thiomonas. Adding lime to the acidic mine drainage caused the precipitation of the amorphous hydrous ferric oxide that adsorbs arsenic, and amorphous scorodite $\mathrm{FeAsO}_{4} 2 \mathrm{H}_{2} \mathrm{O}$ (Boling and Sundkvist 2008). The arsenic removal from a leaching solution was nearly complete at $\mathrm{pH} 3.5$ during biological treatment and scorodite precipitation (Battaglia-Brunet et al. 2011). Despite the partial precipitation or co-precipitation, the environment is poisoned by arsenic.

Arsenic is a toxic metalloid and a common contaminant in a soil. Arsenite and arsenate forms exhibit different behaviours in the environment. The 
mobility conditions for the arsenic from the soil samples collected at an old a Frenche gold mine site were tested (Chatain et al. 2005). The arsenic and iron concentration in the soil samples were 2.7 and $8.9 \%$, respectively. The bioleaching tests were conducted under anaerobic conditions using indigenous bacteria that were separate from the soil samples. Increased arsenic mobilisation was observed after adding extra carbon sources (Johnson 2012).

\section{Bacterial resistance towards the arsenic ions}

Generally, bacteria are sensitive to the high concentrations of arsenic ions. The inhibition of As(III) on the growth of Acidithiobacillus ferrooxidans was observed (Lang et al. 2009). The growth of this bacteria at pH 1.5 was strongly inhibited at $3.310^{-3} \mathrm{M}$ As(III) during the recorded growth time (Mandl et al. 1996). When a gold-bearing concentrate containing arsenopyrite is bioleached the arsenic concentration reaches $12 \mathrm{~g} / \mathrm{dm}^{3}$ for arsenate and $3-6 \mathrm{~g} / \mathrm{dm}^{3}$ for arsenite (Rawlings 2008). Extended contact between bacteria and arsenic ions induces a resistance towards arsenic. Bacteria isolated from the tanks where the arsenopyrite concentrate was bioleached tolerated $1-13 \mathrm{~g} / \mathrm{dm}^{3}$ total arsenic in solution. The research conducted with Acidithiobacillus caldus and Leptospirllum ferriphilum isolated from the arsenopyrite bio-oxidation tanks at the Fairview mine (South Africa) showed that these bacteria contain two sets of arsenic resistance genes (Rawlings 2008).

Bacteria (Acidithiobacillus ferrooxidans) activity and growth rates decrease when the concentration of $\mathrm{As}^{3+}$ increases. When the concentration of $\mathrm{As}^{3+}$ ions reached $6.0 \mathrm{~g} / \mathrm{dm}^{3}$ the $\log$ (logarithm) phase of the bacteria growth lasted $264 \mathrm{~h}$. The bacteria culture growth without the presence of arsenic ions showed the $\log$ (logarithm) phase equalling $24 \mathrm{~h}$ (Cui et al. 2010).

During the industrial bio-pretreatment of gold- and arsenic- containing minerals, high levels of pulp density are needed (10-20\%). Consequently, the arsenic can limit refractory gold ore bio-pretreatment. The effect of the arsenic ion concentration on the growth of the moderately thermophilic bacteria is presented in Fig. 1.

The laboratory experiments were carried out to enable Acidithiobacillus ferrooxidans bacteria to adapt

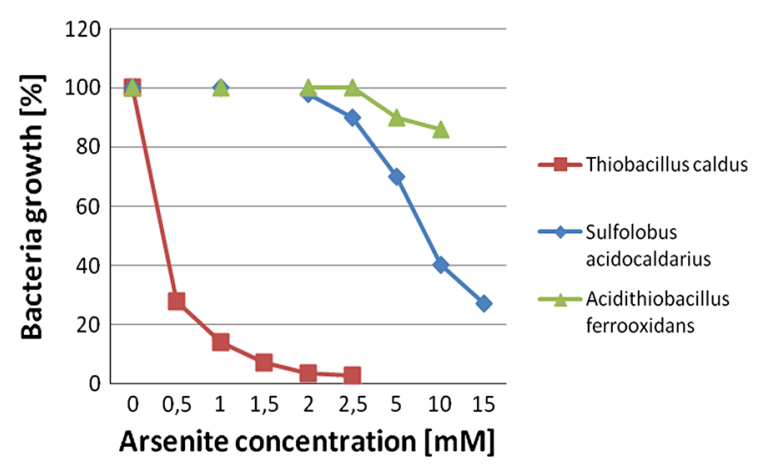

Fig. 1 Bacteria growth measured as the optical density at $440 \mathrm{~nm}$ [according to (Hallberg et al. 1996)]

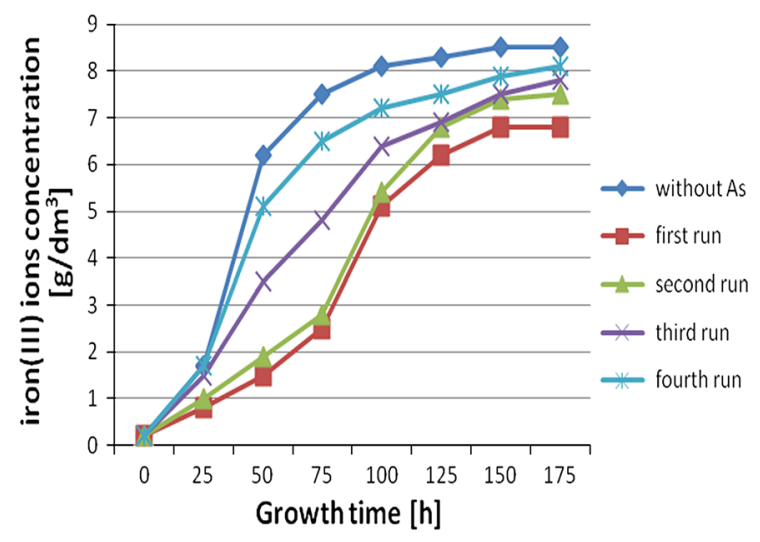

Fig. 2 Bio-oxidation of iron(II) to iron(III) by bacteria adapted to $0.01 \%$ arsenate (Sadowski et al. 2000)

to arsenopyrite (Ospina et al. 2012). The bacteria adapted gradually. The concentration of ferrous sulphate was successively decreased and the concentration of arsenopyrite was subsequently increased. The bacteria population was systematically increased. The effect of the particle size distribution on the adaptation process was also observed. The bacteria easily adapted when the large particle fraction was used (Marquez et al. 2012).

Sadowski et al. (2000) examined the adaptation of Thiobacillus ferrooxidans strains during a series of reputable subculturing in $9 \mathrm{~K}$ medium with different concentrations of arsenic ions. The adaptation was achieved when the kinetics of $\mathrm{Fe}(\mathrm{II})$ ions and the modified bacteria in the presence and absence of arsenic ions were similar (see Fig. 2).

The effectiveness of the fungus called Aspergillus funmigatus towards the bioleaching of arsenic from arsenic-bearing minerals was tested (She-Bardan et al. 2012a). The fungus of Aspergillus fumigates was 
isolated from gold mine tailings. The fungus biomass created during the bioleaching processes can take up ions from the leaching solution. Biosorption is a promising and attractive technology for controlling arsenic pollution (She-Baran et al. 2012b).

\section{Secondary arsenic minerals precipitation}

The secondary arsenate compound formed after oxidising native arsenopyrite is called löllingite, and is also formed from weathered orpiment. In an acidic environment scorodite was the major secondary As mineral (Drahota and Filippi 2009).

The migration of As ions from mine waste is controlled by precipitation-dissolution and adsorption-desorption processes. These processes also affect the secondary arsenic compounds. The genesis of secondary compounds depends on the mineralogy of the original waste materials. Goethite $(\mathrm{FeO}(\mathrm{OH})$, ferrihydrite $\mathrm{Fe}_{2} \mathrm{O}_{3} \quad 0.5 \mathrm{H}_{2} \mathrm{O}$, or amorphous hydrous ferric oxides are precipitated in the presence of excess iron ions (Murciego et al. 2011). The formation of scorodite occured according to the following reaction:

$\mathrm{FeAsS}+14 \mathrm{Fe}^{3+}+10 \mathrm{H}_{2} \mathrm{O}$

$$
\rightarrow 14 \mathrm{Fe}^{2+}+\mathrm{SO}_{4}^{2-}+\mathrm{FeAsO}_{4} 2 \mathrm{H}_{2} \mathrm{O}+16 \mathrm{H}^{+}
$$

Scoridite has a low solubility $\left(<0.5 \mathrm{mg} \mathrm{As} / \mathrm{dm}^{3}\right)$ at $\mathrm{pH}$ values below 3 . The arsenic released from scorodite occurs according to the following reactions:

$\mathrm{FeAsO}_{4} 2 \mathrm{H}_{2} \mathrm{O}+\mathrm{H}_{2} \mathrm{O} \rightarrow \mathrm{H}_{2} \mathrm{AsO}_{4}^{-}+\mathrm{Fe}(\mathrm{OH})_{3}+\mathrm{H}^{+}$

$\mathrm{FeAsO}_{4} 2 \mathrm{H}_{2} \mathrm{O}+\mathrm{H}_{2} \mathrm{O} \rightarrow \mathrm{HAsO}_{4}^{2-}+\mathrm{Fe}(\mathrm{OH})_{3}+2 \mathrm{H}^{+}$

Kaatialaite $\left(\mathrm{Fe}\left(\mathrm{H}_{2} \mathrm{AsO}_{4}\right)_{3} \cdot 5 \mathrm{H}_{2} \mathrm{O}\right)$ is a very rare secondary $\mathrm{Fe}(\mathrm{III})$ arsenate. Kaatialaite is formed in very acidic environments $(\mathrm{pH}<2)$. This secondary arsenic mineral is more stable under acidic conditions than scorodite (Drahota and Filippi 2009). Under acidic conditions, scorodite can be transferred into kaatialaite according to the reaction:

$$
\begin{aligned}
& 3 \mathrm{FeAsO}_{4} 2 \mathrm{H}_{2} \mathrm{O}+6 \mathrm{H}^{+}+3 \mathrm{H}_{2} \mathrm{O} \\
& \quad \rightarrow \mathrm{Fe}\left(\mathrm{H}_{2} \mathrm{AsO}_{4}\right)_{3} 5 \mathrm{H}_{2} \mathrm{O}+2 \mathrm{Fe}^{3+}
\end{aligned}
$$

Arsenic ions released during chemical or biological weathering are susceptible to precipitation with $\mathrm{Fe}$ (III) and $\mathrm{Ca}(\mathrm{II})$. Arseniosiderite is $\mathrm{Ca}_{2} \mathrm{Fe}_{2} \mathrm{O}_{3}\left(\mathrm{AsO}_{4}\right)_{3} \cdot 3 \mathrm{H}_{2} \mathrm{O}$

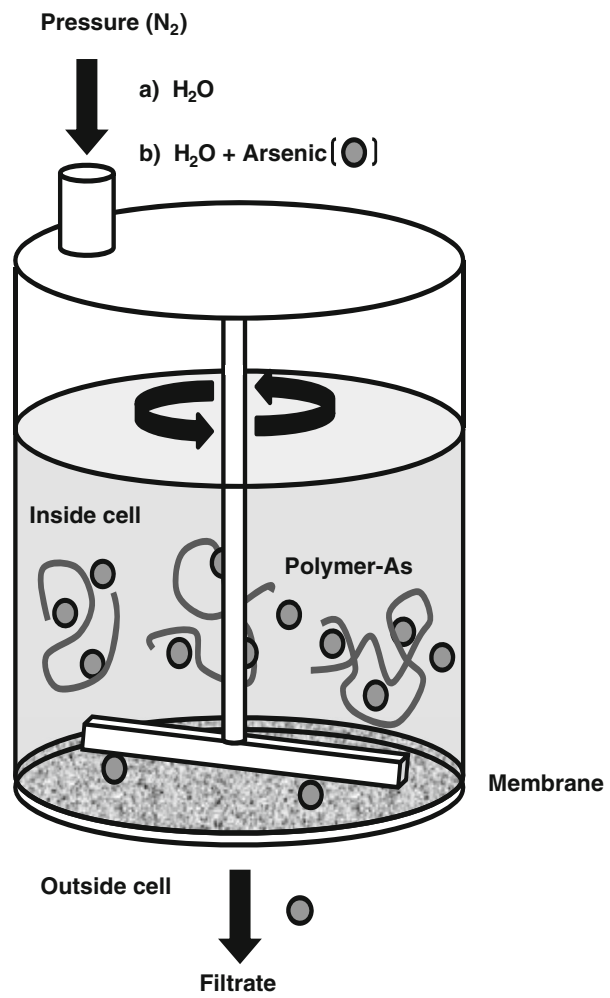

Fig. 3 Procedure for arsenic removal using LPR technique a washing method, $\mathbf{b}$ enrichment method

and exists in neutral natural environments (Drahota and Filippi 2009).

\section{Separation of arsenic ions by functional water-soluble polymers}

The latest materials developed to removed arsenic are water-soluble polymers; when, combined with filtration membranes, these materials can remove arsenic species from aqueous solutions (Sanchez and Rivas 2011).

The liquid-phase polymer-based retention technique (LPR) is also called polymer-assisted ultrafiltration (PAUF), and polymer-enhanced ultrafiltration (PE-UF) is a hybrid method utilising membrane separation with the water-soluble polymer and arsenic ion in contact on the feed-side in a filtration system. The water-soluble polymer interacts and binds with arsenic ions, generating polymer-arsenic ion macromolecules, that are retained primarily via size exclusion mechanism; unbound arsenic species with a diameter smaller than the membrane cut-off diameter, 


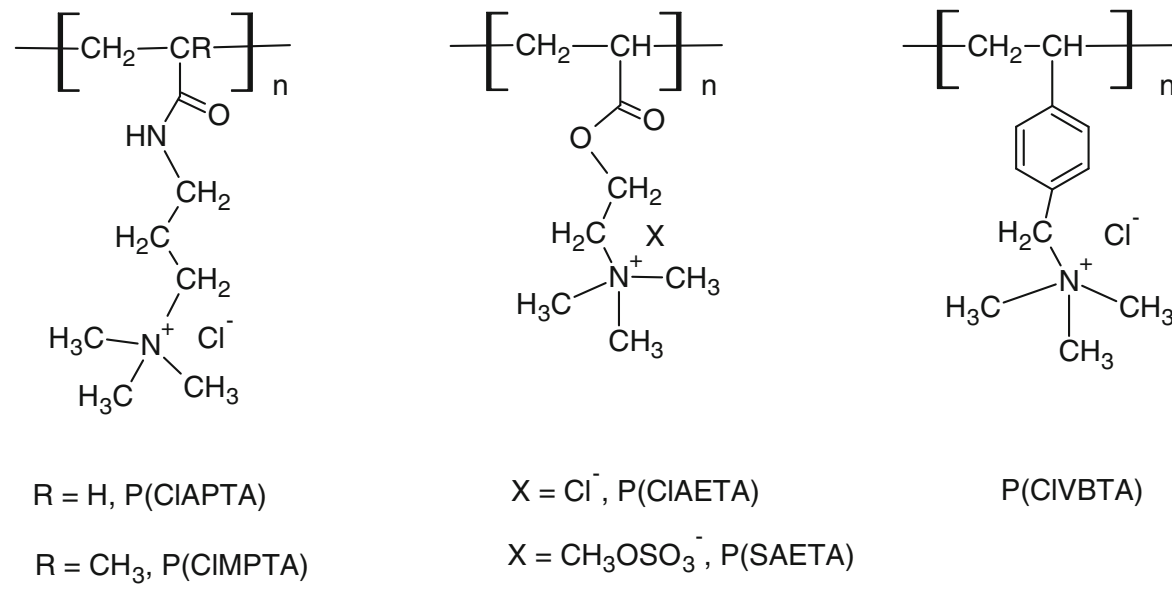

Fig. 4 Structure of some water-soluble polymers containing ammonium groups

pass through the membrane into the permeate stream (see Fig. 3) (Bayer et al. 1985, Rivas 2003, Rivas et al. 2011, 2012, Toledo et al. 2013).

During LPR technique, separation is related to the strength of the interaction between the target ions and the polymer functional groups. During traditional UF, the dissolved particles can be "retained" (larger than pore diameter) and "not retained" (smaller than pore diameter); During LPR, two types of target ions smaller than the membrane pore diameter can be defined as follows: "free target ions in solution" (not retained) and "bound to the polymer" (retained). During LPR, the species of interest are retained depending on their interaction with the polymer and independent of the size (Rivas et al. 2011).

The LPR method is advantageous because it is performed in homogeneous media and largely avoids mass transfer or diffusion, in contrast with heterogeneous methods.

In LPR, two types of procedures can be identified: (a) a washing method, which is an elution method based on continuous diafiltration while adding solvent at constant volume, and (b) an enrichment method, which is a concentration method based on continuous diafiltration by adding solvent and target ions at a constant volume. This procedure enables the maximum retention capacity to be determined.

The polymers used to remove arsenate species contain ammonium side chain groups (see Fig. 4). These functional water-soluble polymers contain different counter-ions and have been synthesised, characterized, and studied to, demonstrate their different arsenic retention abilities.
To study the removal of arsenic ions from ionic solutions using an LPR technique via washing, two factors should be defined: (1) retention (R), which is the fraction of arsenic ions remaining in the cell and (2) filtering factor.

$\mathrm{R}=\left[\mathrm{As}_{\mathrm{cell}}\right] /\left[\mathrm{As}_{\text {init }}\right]$

where $\left(\mathrm{As}_{\text {cell }}\right)$ is the absolute amount of arsenic ions that are retained in the cell, and $\left(\mathrm{As}_{\text {init }}\right)$ is the absolute amount of arsenic ions present at the start of the experiment.

The filtration factor $(\mathrm{Z})$ is the ratio between the total permeate volume $\left(\mathrm{V}_{\mathrm{f}}\right)$ and the retentate volume $\left(\mathrm{V}_{\mathrm{o}}\right)$ :

$\mathrm{Z}=\mathrm{V}_{\mathrm{f}} / \mathrm{V}_{\mathrm{o}}$

\subsection{Effect of $\mathrm{pH}$ on arsenic removal}

The polymers showed a high affinity for interacting with and removing $\mathrm{As}(\mathrm{V})$ species without retaining As(III) species at $\mathrm{pH}$ values from 3 to 9 due to the speciation of As(III) in aqueous media. Different As(III) species are present in solution depending on the $\mathrm{pH}: \mathrm{H}_{2} \mathrm{AsO}_{3}{ }^{-}, \mathrm{HAsO}_{3}{ }^{2-}$, and $\mathrm{AsO}_{3}{ }^{3-}$, with $\mathrm{pK}_{\mathrm{a} 1}=9.2, \mathrm{pK}_{\mathrm{a} 2}=12.1$ and $\mathrm{pK}_{\mathrm{a} 3}=13.4$, respectively. Therefore, at $\mathrm{pH} 9$ the As(III) species are in equilibrium with the non-dissociated salt and the mono arsenic oxy-anion. As $(\mathrm{V})$ species coexist in aqueous media depending on the $\mathrm{pH}: \mathrm{H}_{2} \mathrm{AsO}_{4}$, $\mathrm{HAsO}_{4}{ }^{2-}$, and $\mathrm{AsO}_{4}{ }^{3-} ; \mathrm{pK}_{\mathrm{a} 1}=2.2 ; \mathrm{pK}_{\mathrm{a} 2}=7.0$ and $\mathrm{pK}_{\mathrm{a} 3}=11.5$ (Rivas et al. 2007, 2010).

The retention capacity of the water-soluble polymer is directly related to the exchange of the anionic 
counterion of the quaternary ammonium of the polymer because in these systems the electrostatic interactions dominate. According to the literature, the anionic exchange process prefers divalent ions over monovalent ions under the same conditions (Rivas et al. 2006). This effect can be confirmed using the high retention capacity of $\mathrm{As}(\mathrm{V})$ species and the nonretention of As(III) when using a water-soluble polymer at different $\mathrm{pHs}$ via the LPR technique.

The arsenate retention $(\% \mathrm{R})$ was determined at a

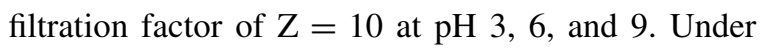
these experimental conditions the total volume of the permeate was $200 \mathrm{~mL}$ and the volume of the retentate in the cell was $20 \mathrm{~mL}$. In the polymer: the $\mathrm{As}(\mathrm{V})$ mole ratio was 20:1.

$\operatorname{As}(\mathrm{V})$ is more easily retained at $\mathrm{pHs}$ between 6 and 9 than more acidic pHs. At pH 3, the monovalent anionic species $\left(\mathrm{H}_{2} \mathrm{AsO}_{4}{ }^{-}\right)$are in equilibrium with the coupled salt. The polarity of the functional group should control the selectivity of the ion exchange (Rivas et al. 2011). At $\mathrm{pH} \mathrm{6,} \mathrm{the} \mathrm{monovalent}$ $\left(\mathrm{H}_{2} \mathrm{AsO}_{4}{ }^{-}\right)$and divalent $\left(\mathrm{HAsO}_{4}{ }^{2-}\right)$ oxy-arsenic species exist in equilibrium, as corroborated by the higher retention capacity of predominantly divalent species at pH 9 by the polymers. The polymer interaction capacity depends on the presence of a positively charged quaternary ammonium group because the interactions are produced using ion exchange between the chloride counter-ion of the quaternary ammonium salt and the arsenate anions (Rivas et al. 2006).

The polymers removed between 55 and $100 \%$ of the arsenate ions at $\mathrm{pH} \mathrm{9,} \mathrm{where} \mathrm{arsenate} \mathrm{is} \mathrm{an} \mathrm{oxy-}$

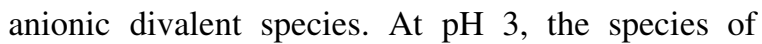
monovalent arsenate is in equilibrium with the coupled salt, and the removal is null.

\subsection{Competitive effect of monovalent and divalent anions on arsenate retention}

The water-soluble polymers with a chloride counterion exhibit the highest retention of arsenate species when using the LPR technique when no other anions are present in solution (Rivas et al. 2011).

To determine the influence of other anions, different experiments were performed in the presence of divalent and monovalent anions, such as a sulphate and chloride using different concentrations of these salts at $\mathrm{pH}$ 8. A washing method was used at different ionic strengths, adding to both the reservoir and the ultrafiltration cell concentrations from $1 \times 10^{-3} \mathrm{M}$ to $1 \times 10^{-1} \mathrm{M} \mathrm{NaCl}$ and $\mathrm{Na}_{2} \mathrm{SO}_{4}$ in separate experiments with a $\mathrm{P}(\mathrm{ClAETA})$ - As(V) mole ratio of 20:1 inside the ultrafiltration cell.

The arsenate retention decreased when increasing the salt concentration and the charge of the additive anion. The decrease in the retention is due to the presence of the added salts decreasing in the following order $\mathrm{Na}_{2} \mathrm{SO}_{4}>\mathrm{NaCl}$.

According to the literature (Berdal et al. 2000), the order of interference in the arsenic retention is as follows: trivalent ions $>$ divalent ions $>$ monovalent ions. The effect of adding electrolytes on arsenic binding with the functional polymers is due to the competition between arsenate and other anions for binding with sites on the polymer. The affinity of the anions when binding the polymer is similar to the behaviour observed in the ion-exchange resin-containing ammonium groups when removing arsenic via ion exchange (Rivas et al. 2011; Berdal et al. 2000).

Sulphate or chloride anions might interfere with the arsenate retention differently. The adsorption of the interfering ions was proven to occur at the same active sites on the polymer, particularly with sulphate, which has a tetrahedral structure and divalent charge at basic $\mathrm{pH}$ values like arsenate. The competition between the arsenate and monovalent chloride was lower than that between sulphate and arsenate.

\section{Conclusions}

The liberation of arsenic ions is connected to the chemical weathering and bioleaching of arsenicbearing minerals. The acidic mine drainage (AMD) resulting from these processes is characterised by a high concentration of arsenic ions. Bacteria contributing to the biogeochemical cycle of arsenic can adapt to high arsenic concentrations. Changing conditions may precipitate secondary arsenic minerals, reducing the arsenic content in water and soil. However, this process does not entirely eliminate the presence of arsenic in the water.

Water-soluble polymers in conjunction with membranes efficiently remove arsenic species. Polymers containing a chloride-exchangin group, show a superior ability for removing arsenate than those containing methyl sulphate as the anion-exchanging group, under 
the same conditions. This behaviour was not affected by interfering ions during arsenate removal.

Acknowledgments This work was supported by the cooperation project of "Innovation materials and methods for water treatment" (CHILTURPOL) and Grant PIA (Anillo ACT-130).

Open Access This article is distributed under the terms of the Creative Commons Attribution License which permits any use, distribution, and reproduction in any medium, provided the original author(s) and the source are credited.

\section{References}

Basu A, Schreiber EM (2013) Arsenic release from arsenopyrite weathering: insights from sequential extraction and microscopic studies. J Hazard Mater (in press)

Battaglia-Brunet F, Crouzet C, Breeze D, Tris H, Morin D (2011) Decreased leachability of arsenic linked to biological oxidation of As(III) in solid wastes from bioleaching liquors. Hydrometallurgy 107:34-39

Bayer E, Spivakov YB, Geckeler K (1985) Poly(ethyleneimine) as a complexing agent for separation of metal ions using membrane filtration. Polymer Bulletin 13(4):307-311

Berdal A, Verrie D, Zaganiaris E (2000) Removal of arsenic from potable water by ion exchange resins. In: Greig JA (ed) Ion exchange at the Millennium, Proceedings of IEX. Imperial College Press, London, pp 101-108

Boling JN, Sundkvist EJ (2008) Two-stage precipitation process of iron and arsenic from acid leaching solution. Trans Nanferrous Met Soc China 18:1513-1517

Bosecker K (1997) Bioleaching: metal solubilization by microorganisms. FEMS Microbiol Rev 20:591-604

Chatain V, Bayard R, Sanchez F, Moszkowicz P, Gourdon R (2005) Effect of indigenous bacteria activity on arsenic mobilization under anaerobic conditions. Environ Int 31:221-226

Cruz R, Lazaro I, Gonzalez I, Monroy M (2005) Acid dissolution influences bacterial attachment and oxidation of arsenopyrite. Miner Eng 18:1024-1031

Cui R-c, Yang H-y, Chen S, Zhang S, K-f Li (2010) Valence variation arsenic in bioleaching process of arsenic-bearing gold ore. Trans Nonferrous Met Soc China 20:1171-1176

Drahota P, Filippi M (2009) Secondary arsenic minerals in the environment: a review. Environ Int 35:1234-1255

Escobar B, Huenupi E, Godoy I, Wiertz VJ (2000) Arsenic precipitation in the bioleaching energite by Sulfolobus BC at $70^{\circ} \mathrm{C}$. Biotechnol Lett 22:205-209

Guo P, Zhang G, Cao J, Li Y, Fang Z, Yang C (2011) Catalytic effect of $\mathrm{Ag}^{+}$and $\mathrm{Cu}^{2+}$ on leaching realgar $\left(\mathrm{As}_{2} \mathrm{~S}_{2}\right)$. Hydrometallurgy 106:99-103

Hallberg BK, Sehlin MH, Lindstrom BE (1996) Toxicity of arsenic during high temperature bioleaching of gold-bearing arsenical pyrite. Appl Microbiol Biotechnol 45:212-216

Igarashi T, Imagawa H, Uchiyama H, Asakura K (2008) Leaching behavior of arsenic from various rocks by controlling geochemical conditions. Miner Eng 21: 191-199.kvist

Johnson BD (2012) Reductive dissolution of minerals and selective recovery of metals using acidophilic iron- and sulfate reducing acidophiles. Hydrometallurgy 127-128:172-177
Jong T, Parry LD (2005) Evaluation of the stability of arsenic immobilized by microbial surfate reduction using TCLP extractions and long-term leaching technique. Chemosphere 60:254-265

Lang F, Li K, Zhang X, Li Y, Zhu Y, Lu J, Li H (2009) Comperative study of inorganic arsenic resistance of several strains of Acidithiobacillus thiooxidans and Acidithiobacillus ferrooxidans. Hydrometallurgy 98:235-240

Lengker FM, Tempel NR (2003) Natural realgar and amorphous AsS oxidation kinetics. Geochemica Cosmochimica Acta 67(5):859-871

Mandl M, Hrbac D, Dodekolova H (1996) Inhibition of iron(II) oxidation by arsenic (II, V) in Thiobacillus ferrooxidans: effects on arsenopyrite bioleaching. Biotechnol Lett 18(3):333-338

Marquez AM, Ospina DJ, Morales LA (2012) New insights about the bacteria oxidation of arsenopyrite: a mineralogical scope. Miner Eng 39:248-254

Murciego A, Alvarez-Ayuso E, Pellitero E, Rodriguez AM, Garcia-Sanchez A, Tamayo A, Rubio J, Rubi F, Rubin J (2011) Study of arsenopyrite weathering products in mine wastes from abandoned tungsten and tin exploitations. J Hazard Mat 186:590-601

Ospina DJ, Restrepo ME, Bedoya OL, Marquez AM, Morales LA (2012) Biooxidacio de concentrados de arsenopiryte por Acidithiobacillus ferrooxidans en erlemeyer agitados. Rev Colomb Biotecnol 14(1):135-145

Rawlings ED (2008) High level arsenic resistance in bacteria present in biooxidation tanks used treat gold-bearing arsenopyrite concentrates: a review. Trans Nonferrous Met Soc China 18:1311-1318

Rivas BL (2003) Water-soluble polymer-metal ion interactions, Pereira E.D., Moreno-Villoslada I. Prog Polym Sci 28:173-208

Rivas BL, Aguirre MC, Pereira E (2006) Retention properties for arsenate anions of water-soluble polymers by liquidphase polymer based retention technique. J Appl Polym Sci 102:2677-2684

Rivas BL, Aguirre MC, Pereira E (2007) Cationic water-soluble polymers with ability to remove arsenate using ultrafiltration technique. J Appl Polym Sci 106:89-94

Rivas BL, Pereira ED, Palencia M, Sánchez J (2011) Watersoluble functional polymers in conjunction with membranes to remove pollutant ions from aqueous solutions. Prog Polym Sci 36:294-322

Rivas BL, Pereira ED, Paredes J, Sánchez J (2012) Removal of arsenate from ionic mixture by anion exchanger watersoluble polymers and Ultrafiltration membranes. Polym Bull 69:1007-1022

Sadowski Z, Farbiszewska T, Farbiszewska-Bajer J, Latalo A (2000) Adaptacja szczepów bakterii Thiobacillus ferrooxidans do zwiększonego stężenia arsenu w podłożu. Prace Naukowe Instytut Górnictwa 88:47-52

Sánchez J, Rivas BL (2011) Hydrophilic polymers and their arsenate retention properties in aqueous solution through ultrafiltration membranes. Desalination 270:57-63

She-Bardan JB, Othman R, Abd Wahib S, Husin A, SadeghZadeh F (2012a) Collumn bioleaching of arsenic and heavy metals from gold mine tailings by Aspergillus fumigates. Clean Soil Air Water 40(6):607-614

She-Bardan JB, Othman R, Abd Wahib S, Sadegh-Zadeh F, Husin A (2012b) Biosorption of heavy metals in leachate 
derived from gold mine tailings using Aspergillus fugatus. Clean Soil Air Water 41(4):356-366

Song J, Lin J, Cao L, Lin J, Qu Y (2008) Modeling and simulation of energite bioleaching. Chin J Chem Eng 16(5): 785-790

Suess E, Planer-Friedrich B (2012) Thioarsenate formation upon dissolution of orpiment and arsenopyrite. Chemosphere 89:1390-1398
Tareq MS, Safiullh S, Anawar MH, Rahman MM, Ishizuka T (2003) Arsenic pollution in-organizing complex geochemical process in the deltaic sedimentary environment, Bangladesh. Sci Total Environ 313:213-226

Toledo L, Rivas BL, Urbano B, Sánchez J (2013) Novel watersoluble polymer based on $N$-methyl-D-glucamine and its potential application to remove arsenic. Sep Pur Technol 103:1-7 